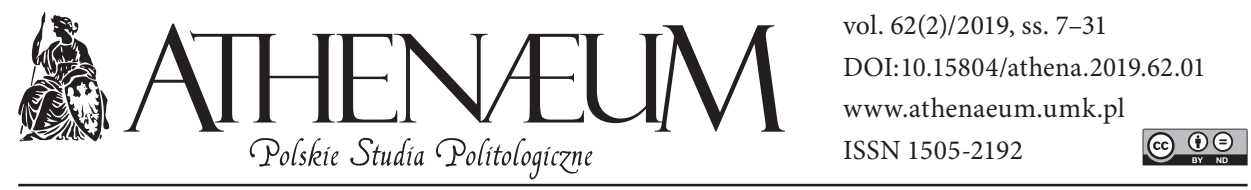

\title{
KAPITAŁ SPOŁECZNY JAKO CZYNNIK ROZWOJU SPOŁECZEŃSTWA I PAŃSTWA
}

\author{
SOCIAL CAPITAL AS THE FACTOR OF THE SOCIETY \\ AND THE STATE DEVELOPMENT
}

Mateusz Radziszewski*

\begin{abstract}
ABSTRAKT
Niniejszy artykuł traktuje na temat społeczeństwa obywatelskiego jako potencjalnego instrumentu mogącego wpłynąć na podniesienie jakości demokratycznego systemu politycznego. Ukazanie źródeł sfery obywatelskiej oraz wskazanie na czynniki ją sankcjonujące, poprzez wykorzystanie koncepcji kapitału społecznego, umożliwia pogłębioną analizę relacji społecznych w wymiarze społecznym, jak i politycznym. W tym celu należy odwołać się do szerokiego dorobku badaczy z zakresu nauk społecznych, których efektem będzie modelowa analiza zjawiska tworzenia się społeczeństwa obywatelskiego oraz jego potencjalnych efektów dla całego systemu politycznego.
\end{abstract}

Słowa kluczowe: kapitał społeczny; demokracja; społeczeństwo; państwo; modernizacja
This article takes into consideration the civil society as the interest tool for improvement of the quality of the democratic political system. For this purpose, it is necessary to find the roots of civic activities. The social capital will be a helpful conception in this process. The aim of this analysis is to present social capital and civil society development basing on a few models and a brief academic research. It enables to determine if it is possible to create a more effective and plural democratic system for citizens.

Keywords: civil society; democracy; society; social capital; political participation

* Uniwersytet Łódzki, Wydział Studiów Międzynarodowych i Politologicznych. 


\section{UWAGI WSTĘPNE}

Jednym z kluczowych problemów współczesnych demokracji jest kryzys zaufania do instytucji państwa i elit politycznych. Efektem tego jest w ostatniej dekadzie wzrost poparcia dla skrajnych partii politycznych w Europie. Te nowe podmioty polityczne, częściej odwołujące się do emocji niż do rozsądku wyborców, opierają swoją działalność na demagogii i populistycznych hasłach. Co ważniejsze, ich największym atutem w oczach społeczeństwa jest wizerunek osób niepochodzących $\mathrm{z}$ dotychczasowego establishmentu (Hartleb, 2015).

W konsekwencji rywalizacja wyborcza pomiędzy nowymi a dotychczasowymi aktorami sceny politycznej przybiera coraz bardziej populistyczny charakter (Howorth \& Schmidt, 2016; Greven, 2016). Przykładem tego jest referendum z czerwca 2016 roku w Wielkiej Brytanii, dotyczące opuszczenia Unii Europejskiej przez Wielką Brytanię (Howorth \& Schmidt, 2016). Wbrew założeniom nie przyniosło ono Davidowi Cameronowi silnego mandatu do sprawowania władzy, kończąc jego karierę jako premiera Rządu Jej Królewskiej Mości. Wyniki głosowania wprowadziły społeczeństwo w konsternację; czy podjęta przez ogół decyzja była słuszna? Przykładów erozji zaufania społeczeństwa do elit politycznych jest więcej. Skrajne i nonkonformistyczne hasła wyborcze pozwoliły odnieść sukces wyborczy niemieckiemu ugrupowaniu Alternatywa dla Niemiec (Alternative für Deutschland - AfD), francuskim nacjonalistom z Frontu Narodowego, antyestablishmentowemu Pawłowi Kukizowi, wpierw w wyborach prezydenckich, a później parlamentarnych jego komitetowi wyborczemu Kukiz'15. Symbolem tych przemian stał się sukces wyborczy Donalda Trumpa, kandydata na 45. Prezydenta Stanów Zjednoczonych, którego początkowo nikt nie traktował poważnie. Kolejne wydarzenia wieńczące wybory 8 listopada 2016 roku sprawiły, że dotychczas ekscentryczny biznesmen z Nowego Yorku stał się przywódcą najpotężniejszego mocarstwa na świecie. Amerykańskie media podkreślają, że dla jego sukcesu ważne nie było to, kim był, ale kim nie był jako kandydat, a nie był osobą utożsamianą z Partią Demokratyczną i Republikańską (Gallo, 2017). Nie był on utożsamiany z dotychczasową polityką, która doprowadziła do kryzysu ekonomicznego w 2008 roku, jak również nie przyczynił się do śmierci wielu Amerykanów w konflikcie na Bliskim Wschodzie. To nie jedyne problemy współczesnej demokracji

Nawracający kryzys ekonomiczny, nieustające ataki terrorystyczne fanatyków religijnych Państwa Islamskiego oraz szeroka fala napływu uchodźców z niebezpiecznych i pogrążonych w biedzie rejonów świata, znacząco wpłynęły na per- 
cepcję społeczeństw państw zachodnich. W obliczu takich problemów staje dziś współczesna demokracja. Uzasadnione są obawy o jej obecną kondycję i przyszły obraz. W rozważaniach nad tą sferą polityki warto odwołać się do klasyków, których zdaniem państwo o ustroju demokratycznym może być jedynie wtedy dobrze prosperujące, gdy społeczeństwo nabierze charakteru obywatelskiego. Jego członkowie, posiadając odpowiednią wiedzę polityczną, dążą do wpłynięcia na proces polityczny, jednocześnie realizując swoją wolność. Uważa się, że jakość społeczeństwa obywatelskiego determinuje stan całego systemu politycznego. Jak stwierdził Arystoteles, to koinonia politike (wspólnota polityczna), stanowi początek państwa (Arystoteles). To wreszcie owo societas civilis (społeczeństwo obywatelskie) Cycerona, określa charakter i ład całej republiki (Skinner, 1978). Z tej perspektywy to państwo jest najwyższym dobrem, jednakże rozumianym jako wspólnota celu, w której każdy jest równy wobec prawa, a najwyższa władza należy do obywateli (Pietrzyk-Reeves, 2012, s. 27).

W obliczu problemów współczesnej polityki warto zastanowić się nad tym, czy rozwój społeczeństwa obywatelskiego może wpłynąć na poprawę systemu politycznego państwa? Następnie w jaki sposób może ono stać się instrumentem odnowy kultury politycznej, usprawniającym proces polityczny? Hipotezą przyświecającą tym rozważaniom będzie stwierdzenie, że społeczeństwo obywatelskie stanowi czynnik regulujący udział obywateli w procesach politycznych toczących się w państwie. Kolejnym obszarem rozważań, którego nie można pominąć, jest kwestia dotycząca sposobów tworzenia się społeczeństwa obywatelskiego oraz to, co sprawia, że mówimy o jego bardziej lub mniej rozwiniętej formie. W tym celu należy postawić hipotezę mówiącą, że kapitał społeczny stanowi czynnik determinujący jakość społeczeństwa obywatelskiego oraz całego systemu politycznego.

Niniejsza praca ma charakter deskryptywno-eksplanacyjny i jest próbą prezentacji założeń teoretycznych z zakresu badań nad rozwojem państwa i społeczeństwa w wymiarze kształtowania się postaw obywatelskich, które w praktyce mogą przyczynić się do efektywniejszego identyfikowania problemów społeczno-politycznych i ich rozwiązywania. Wydaje się, że cel ten jest istotny nie tylko z perspektywy badań politologicznych, ale również funkcjonowania systemu politycznego. Tylko dzięki naukowej wnikliwości można dostrzec pewne problemy, których rozwiązanie może wpłynąć pozytywnie na jakość toczącego się obecnie procesu politycznego, bez rewolucyjnej zapalczywości i hałaśliwego populizmu. 


\section{SPOŁECZEŃSTWO OBYWATELSKIE W DEMOKRACJI}

Demokracja stanowi naturalny obszar aktywności społeczeństwa obywatelskiego. W sposób najbardziej ogólny należy je rozumieć jako wszelką działalność społeczeństwa, wynikającą z jej tradycji i doświadczeń, której celem jest samorządna organizacja swojego życia społecznego i obszaru zamieszkania. Według Roberta Putnama społeczeństwo obywatelskie to: „wzory zaangażowania społecznego i solidarności społecznej” (Putnam, 1993, s. 126). Jest ono zatem sumą przeżyć i doświadczeń członków społeczeństwa. Według Francisa Fukuyamy są one kumulowane poprzez podejmowaną aktywność w rozmaitych grupach i instytucjach, takich jak: „komitety rodzicielskie, organizacje kontroli standardów w życiu publicznym, czy organizacje rzecznictwa interesów poszczególnych środowisk" (Fukuyama, 2005, s. 46). Wykazując swoje zaangażowanie, staje się ono aktywnym i istotnym podmiotem kształtującym państwo. Dał temu dowód Alexis de Tocqueville, który obserwował rodzące się społeczeństwo Stanów Zjednoczonych: „Podczas pobytu w Stanach Zjednoczonych miałem okazję obserwować mieszkańców hrabstwa, w którym popełniono zbrodnię; spontanicznie tworzyli oni komitety mające na celu ściganie winnego i oddanie go w ręce sądu. W Stanach Zjednoczonych przybysze niedawno osiedlili się na zamieszkiwanej dziś ziemi, nie łączą ich z nią zwyczaje ani wspomnienia. Spotkali się tam ludzie, którzy wcześniej się nie znali. Instynktowna miłość ojczyzny nie miała więc tam dobrego gruntu. Jakże więc doszło do tego, że każdy człowiek interesuje się sprawami swojej gminy, hrabstwa i całego stanu tak, jak swymi własnymi? Otóż dzieje się tak dlatego, że każdy w swoim zakresie bierze żywy udział w rządzeniu społeczeństwem” (Tocqueville, 2005, s. 172).

Znaczenie społeczeństwa obywatelskiego w politycznym procesie tworzenia i funkcjonowania państwa podkreślane jest powszechnie niemal przez wszystkich badaczy. Pytaniem otwartym pozostaje jednak umiejscowienie tego podmiotu politycznego. Według Andrzeja Chodubskiego społeczeństwo obywatelskie stanowi opozycję „wobec państwa, które stara się poddać swej kontroli wszystkie sfery życia społecznego; wspólnota wolnych i różnych obywateli, którzy łączą się w celu osiągnięcia wysokiego poziomu życia; a ze wspólnoty nie można nikogo wykluczyć” (Chodubski, 2012, s. 130). Jego zdaniem jest ono: „ideałem organizacji społeczeństwa, które powinno charakteryzować się współdziałaniem wolnych i równych obywateli zamieszkujących na określonym terytorium, mających na celu dobro wspólne" (2009, s. 165). Podobnie uważa Benjamin Barber, określając społeczeństwo obywatelskie jako przestrzeń do współpracy 
obywateli: „Społeczeństwo obywatelskie to przestrzeń obywatelska zajmująca miejsce pośrednie między władzą państwową a sektorem prywatnym. To nie tutaj głosujemy i nie tutaj sprzedajemy i kupujemy, lecz rozmawiamy z sąsiadami na temat przeprowadzania dzieci przez jezdnię, planujemy imprezę charytatywną na rzecz szkoły, zastanawiamy się, czy nasza parafia mogłaby utworzyć schronisko dla bezdomnych, organizujemy letnie zawody sportowe dla dzieci. (...) Społeczeństwo to tworzą z własnej woli swobodnie stowarzyszone jednostki i grupy dążące do wytworzenia wspólnej płaszczyzny działania" (Barber, 2001, s. 360-361).

Fundamentalnym pytaniem dotyczącym społeczeństwa obywatelskiego jest pytanie o jego źródła. Nie ulega wątpliwości, że to od woli jednostek zależy to, czy będą skłonne być aktywne w sferze publicznej. Według Putnama to tradycja i doświadczenia ludzi wpływa na kształt społeczeństwa obywatelskiego, ale nie tylko. Efektem tego oddziaływania jest poziom rozwoju społecznego, ekonomicznego i politycznego wspólnoty. Analizując włoski lokalny samorząd, Putnam stwierdził, że społeczeństwo obywatelskie, jego kształt, jakość oraz zasięg determinuje funkcjonowanie całego systemu politycznego. Konstatacja ta skłoniła go do poszukiwania fundamentalnych czynników stanowiących o rozwoju państwa i społeczeństwa. W swej publikacji Demokracja w działaniu. Tradycje obywatelskie we współczesnych Włoszech zapytał: „Dlaczego niektóre demokratyczne rządy odnoszą sukcesy, a inne przegrywają?”; „Dlaczego niektóre społeczeństwa rozwijają się, a niektóre pozostają w stanie stagnacji lub dążą ku upadkowi?” oraz „dlaczego jedni ludzie świetnie sobie radzą, a inni żyją w nędzy?” (Putnam, 1993, s. 13).

Wydaje się, że społeczności o bardziej rozwiniętym poziomie zaufania, zdolności do kooperacji oraz przedsiębiorczości sprawniej podejmują decyzje biznesowe oraz w sposób bardziej odpowiedzialny i świadomy biorą udział w procesie politycznym. Zdaniem Johna Locke’a ta ostatnia działalność winna odbywać się w duchu konsensusu, gdyż tylko dialog i kooperacja może być podstawą istnienia państwa „dla zachowania siebie i reszty rodzaju ludzkiego” (Lock, 1993, s. 253). W opinii angielskiego filozofa taka wspólnota posiada również inną ważną cechę, a mianowicie składa się z wolnych ludzi, którzy stoją przed państwem i społeczeństwem, a więc ich prawa są najważniejsze. Mamy zatem do czynienia ze wspólnotą obywateli, równych sobie w swoich prawach i wolnościach, na podstawie których podejmują oni współpracę oraz prowadzą ciągły dialog. Mniej idealistyczny pogląd na tę sferę życia wyraził Thomas Hobbes, który również wskazał na potrzebę współpracy i dialogu w społeczeństwie, jednakże 
nie z pobudek altruistycznych, lecz dla zachowania swojego bezpieczeństwa od zagrożeń „przedpolitycznego świata, czyli wojny wszystkich ze wszystkimi” (Hobbes, 1954, s. 113-185).

Społeczeństwo obywatelskie nie stanowi nierealnego bytu czy koncepcji czysto teoretycznej. Jest ono ważnym obszarem życia politycznego i społecznego, a od jego funkcjonalność zależy wiele aspektów życia. Wskazując na problematykę partycypacji obywatelskiej, czyli zaangażowaniu zarówno w wymiarze politycznym, jak i społecznym, należy zwrócić uwagę na istotność relacji społecznych w tym procesie. To od ich charakteru, zasięgu i jakości zależy ich skuteczność. Zdaniem Norberta Eliasa „czy [ludzie] mają ze sobą do czynienia jako przyjaciele, czy jako wrogowie, rodzice czy dzieci, mąż i żona, rycerz i chłop pańszczyźniany, król i poddani, menedżer i pracownicy, wszystkie [ich] zachowania są określone przez przeszłe lub teraźniejsze stosunki z innymi ludźmi” (Elias, 2008, s. 26). Należy więc stwierdzić, że relacje społeczne oraz wynikające z nich doświadczenia determinują nasze obecne i przyszłe zachowanie i opinie. Co zatem sankcjonuje jakość owych relacji? Gdy chodzi o zakup samochodu lub mieszkania, dla udanej transakcji konieczne jest zaufanie kupującego do sprzedającego, a także uczciwe zasady i reguły zawarte w sporządzonej między stronami umowie. Niekiedy ważną rolę odgrywa tzw. poręczenie, czyli dobra opinia innych na temat sprzedającego, których osądom zawierzamy. Na płaszczyźnie politycznej przykładem mogą być projekty ustaw, które by zostały wdrożone w życie muszą uzyskać większość głosów członków parlamentu. Tutaj również kluczową rolę odgrywają relacje między poszczególnymi parlamentarzystami, a mianowicie: czy ufają autorowi danego projektu ustawy oraz czy utożsamiają się formalnie lub nieformalnie z określoną grupą polityczną (partią polityczną i/lub klubem poselskim). Wynika z tego, że funkcjonowanie społeczeństwa obywatelskiego w bezpośredni sposób zależy od jakości relacji społecznych. Zdaniem Piotra Sztompki: „(...) jeśli chcę zorganizować stowarzyszenie dla jakiegoś wspólnego celu, muszą znaleźć się chętni, którzy się do niego zapiszą, jeśli gram w drużynie piłkarskiej i strzelam gola, inny zawodnik musi mi podać piłkę, jeśli chcę być wybrany na reprezentanta innych w Sejmie, oni muszą na mnie zagłosować (...)" (Sztompka, 2016, s. 12).

Wskazał on również, że ich przebieg zależy od tzw. „przestrzeni moralnej” jej uczestników, która opiera się na zaufaniu, lojalności, wzajemności, solidarności, szacunku i sprawiedliwości (Sztompka, 2016). Jednym z badaczy relacji społecznych był Georg Simmel, który zafascynowany rozwiązaniami matematycznymi, starał się wykorzystać je w analizie zjawisk społecznych. Efektem jego 
prac było stworzenie „geometrii społecznej”, będącej procesem analizy relacji międzyludzkich, ich klasyfikacji oraz poszukiwania prawidłowości (Simmel, 1964, 1971, 2006). Dokonania tego uczonego wpłynęły na późniejszych badaczy, którzy skupili swoją uwagę na analizie kontaktów międzyludzkich, zawartych w szerokim kontekście norm i wartości społecznych (Turner, 2002). Ponadto zostało dostrzeżone, że proces wchodzenia w relacje społeczne pozostawia w świadomości ludzi tzw. „łańcuchy interakcyjne”, które w znaczącym stopniu wpływają na percepcję człowieka oraz późniejsze jego decyzje i działania (Collins, 2004). Zjawisko to zauważył już Erving Goffman, który uznał, że „(...) nasze życie codzienne upływa w bezpośredniej obecności innych ludzi” (Goffman, 1983, s. 2).Zdaniem Simmela to, z kim utrzymujemy kontakt, sprawia, że wypracowujemy swój kulturowy kod genetyczny oraz wzory uczestnictwa (Simmel, 1964, s. 141). Stwierdził on że: „Niezliczone są formy życia społecznego: bycia $z$ innym, dla innego, $w$ innym, (...) poprzez innego, w państwie i we wspólnocie, w kościele i stowarzyszeniu przemysłowym, w rodzinie i w klubie" (1971, s. 23).

Kolejnym aspektem funkcjonowania społeczeństwa obywatelskiego jest pewna dyspozycja jednostek do aktywności obywatelskiej. Cytując słowa jednego z twórców konstytucji amerykańskiej, Jamesa Madisona, można powiedzieć, iż „sądzić, że pewna forma rządu zapewni wolność i szczęście bez rozwiniętych cnót obywatelskich, to chimera" (Sztompka, 2016, s. 14). Wynika z tego, że bycie świadomym obywatelem oznacza dysponowanie pewnym kapitałem moralnym, który umożliwia życie we wspólnocie. Należy jednak pamiętać, że procesy historyczne kształtujące nasze życie nie przebiegają w sposób płynny i jednoznaczny. Nie można zatem jednoznacznie stwierdzić, że słabe rządy w państwie wynikają z niskiej jakości jego społeczeństwa. Należy tu odwołać się do koncepcji trzech zegarów stworzonej przez Ralfa Dahrendorfa. Pierwszym z nich jest zegar polityczny i biegnie on najszybciej. Kolejnym nieco wolniejszym jest zegar ekonomiczny, będący efektem przemiany gospodarczej państwa. Ostatnim z nich jest zegar społeczeństwa obywatelskiego. Jest on najwolniejszy, ponieważ wymaga przemian w mentalności i kulturze społeczeństwa (1990). Badania Roberta Putnama, dotyczące tradycji obywatelskich wśród Włochów, są ciekawym przykładem tego rodzaju przemian. Na północy kraju, gdzie historyczne towarzystwa basztowe, stowarzyszenia samopomocowe czy kluby piłkarskie były dowodem na istnienie norm wzajemności oraz sieci obywatelskiego zaangażowania, udało się osiągnąć wysoki poziom gospodarczy oraz wysoką efektywność instytucji politycznych. Z kolej na południu, gdzie stosunki społeczne są w dużej mierze hierarchiczne, efekty są dużo gorsze (1993, s. 284). Kwestią kluczową, 
określającą tę dychotomię, jest różne rozumienie pojęcia „solidarność”. Kiedy robotnicy w gdańskiej stoczni skandowali, że „Nie ma wolności bez solidarności”, z pewnością nie chodziło im tylko o niezależny związek zawodowy, lecz o ową solidarność międzyludzką. Niestety nie jest ona zawsze jednoznaczna. Edward Banfield określił jej wypaczoną formę jako „amoralny familizm” (Banfield, 1958). Odznacza się on tym, że poczucie więzi i wspólnoty grupy opiera się głównie na ślepej lojalności wobec niej samej i jej lidera. Celem istnienia tego rodzaju podmiotu jest zapewnienie własnych partykularnych interesów kosztem innych członków społeczeństwa. Przykładami takich instytucji są organizacje mafijne, grupy terrorystyczne czy sekty religijne.

Obecnie trwa szeroka dyskusja na temat społeczeństwa obywatelskiego, jako instrumentu naprawy demokracji. Nie jest ono jednak panaceum na wszelkie problemy polityki. Bezrefleksyjne wykorzystywanie tego pojęcia może doprowadzić do błędnych diagnoz. Jak słusznie zauważył Joseph Schumpeter, samo wkroczenie w sferę polityki znacząco wpływa na percepcję potrzeb i problemów społecznych. Poddał on w wątpliwość zasadność klasycznej teorii demokracji, uznając, że „(...) metoda demokratyczna jest tym rozwiązaniem instytucjonalnym dochodzenia do decyzji politycznych, w którym jednostki uzyskują moc decydowania poprzez walkę konkurencyjną o głosy wyborców" (Schumpeter, 2003, s. 269). Schumpeter w sposób pragmatyczny opisał aktywność obywatelską społeczeństwa. Jego zdaniem wraz $\mathrm{z}$ wchodzenie ludzi $\mathrm{w}$ sferę polityki ich poziom racjonalności i poczucia dobra wspólnego maleje z powodu dążeń do zrealizowania własnych prywatnych interesów: „(...) typowy obywatel, skoro tylko wkracza w sferę polityki, spada na niższy poziom sprawności umysłowej. Argumentuje on i analizuje w sposób, który w zastosowaniu do sfery swoich realnych interesów sam bez trudu uznałby za infantylny. Staje się na powrót prymitywem. Jego myślenie nabiera cech emocjonalnych i asocjacyjnych (...)" (2003, s. 262).

Schumpeter podkreślił również rolę i znaczenie profesjonalnych polityków, którzy zdolni są do formatowania poglądów obywateli dla własnych interesów politycznych: „Im słabszy jest element logiczny w procesach zachodzących w świadomości społecznej oraz im bardziej brakuje racjonalnego krytycyzmu i racjonalizującego wpływu osobistego doświadczenia i odpowiedzialności, tym większe się otwierają możliwości dla grup o ukrytych i często egoistycznych interesach. Grupy te mogą składać się z zawodowych polityków (...); To zaś w dalszej kolejności decyduje o tym, że typowy obywatel będzie raczej skłonny ustąpić pod naciskiem pozaracjonalnych lub irracjonalnych uprzedzeń i impulsów (...)" (2003, s. 262). 
Stwierdził on również, że aktywność obywatelska społeczeństwa, prędzej czy później, przestanie być racjonalnym i konsensualnym dążeniem do podjęcia decyzji politycznej. W tym wymiarze społeczeństwo przedstawia się jako tłum, u którego, zdaniem Le Bona, „zanika zdolność rozumowania, brakuje krytycyzmu, pojawia się drażliwość, łatwowierność i prostota uczuć” (Le Bon, 2004, s. 82; Masłyk, 2014, s. 107). Wedle tego poglądu jakość partycypacji politycznej jest raczej wypadkową emocjonalnej dyspozycji członków społeczeństwa niż roztropną pracą na rzecz dobra publicznego. Powyższe konstatacje skłaniają do stwierdzenia, że od osób podejmujących aktywność obywatelską winno się wymagać merytoryczności i uczciwości. Jak zatem sprawić, aby osoby biorące udział w życiu politycznym odznaczały się tymi cechami? Wydaje się zasadne zwrócenie swej uwagi na koncepcję kapitału społecznego, która pozwala ukazać podstawowe wymiary rozwoju relacji społecznych, aktywności obywatelskiej, a przede wszystkim czynników umożliwiających zachowanie spójności i stabilności całego systemu w państwie. Metaforą tych relacji mogą być słowa Davida Hume'a, który w Traktacie o naturze ludzkiej przedstawił pogląd na temat funkcjonowania państwa i społeczeństwa oraz zdanie, do czego prowadzi współdziałanie obywatelskie, a w szczególności jego brak. „Twoje zboże jest dojrzałe już dzisiaj; moje dojrzeje dopiero jutro. Jest korzystne dla nas obu, iżbym ja pracował dzisiaj z tobą i żebyś ty pomógł mi jutro. Ja nie żywię do ciebie żadnej przychylności, a ty również nie żywisz jej do mnie. Nie podejmę żadnych wysiłków dla twojego dobra; gdybym pracował z tobą dla mego własnego dobra w oczekiwaniu świadczenia wzajemnego, to wiem, że czekałoby mnie rozczarowanie i że na próżno uzależniłbym się od twej wdzięczności. Tutaj więc pozostawiam cię przy twej pracy samego, a ty robisz to samo ze mną. Zmienia się pogoda i obaj tracimy nasze zbiory z braku wzajemnego zaufania i poczucia pewności" (Hume, 1739, s. 175).

Z powyższej analizy badań nad rozwojem społeczeństwa obywatelskiego należy wyciągną wniosek, że jest to sfera działalności człowieka ukierunkowana na rzecz państwa jako wspólnoty wolnych obywateli. Może być ona rozpatrywana $w$ dwóch wymiarach. Pierwszym $z$ nich jest partycypacja społeczna, czyli oddolne współdziałanie obywateli w celu poprawy własnego bytu. Kolejny to partycypacja polityczna, ukierunkowana na realizację wspólnych interesów politycznych poprzez, na przykład, udział w wyborach - wybór własnej reprezentacji politycznej oraz udział w demonstracjach - artykulacja sprzeciwu lub aprobaty wobec polityki prowadzonej przez sprawujących władzę w państwie. W obu przypadkach niezbędne dla badacza jest zrozumienie źródeł owej aktywności 
oraz ukazanie zmiennych, które umożliwią nakreślenie jej realistycznego obrazu, a także efektów, jakie może ona przynieść. W tym celu niezbędnym instrumentem staje się kapitał społeczny.

\section{IDEA KAPITAŁU SPOŁECZNEGO}

Dotychczasowe rozważania dotyczące kształtowania społeczeństwa obywatelskiego pozwalają wysunąć na pierwszy plan trzy kluczowe czynniki określające jego zasięg oraz jakość. Jednym z nich jest zaangażowanie jednostek w ramach różnych wspólnot i grup społecznych. Kolejnym podkreślanym przez badaczy jest tzw. dyspozycja moralna, czyli wartości i normy etyczne, które pozwalają na uczciwą i partnerską kooperację ludzi. Ostatnią determinantą rozwoju jakości relacji społecznych jest zmienny poziom wzajemnego zaufania osób, chętnych do wzięcia udziału zarówno w procesie partycypacji społecznej, jak i politycznej. W celu dokonania analizy owej problematyki należy zwrócić uwagę na istotę kapitału społecznego.

W dyskursie naukowym pojęcie „kapitał społeczny” pojawiło się na początku XX w., za sprawą Lyda Judsona Hanifana, który w 1916 roku użył go, opisując wiejskie ośrodki edukacyjne. Zdaniem badacza jest to pewien zestaw niematerialnych wartości wspólnotowych, takich jak: życzliwość, koleżeństwo, solidarność oraz kontakty społeczne pomiędzy członkami społeczności lokalnej i ich rodzinami (Hanifan, 1916, s. 130-138). Kapitał społeczny stanowi zatem zestaw zmiennych kształtujących świadomość i działalność ludzi. Z tego względu pojęcie to doczekało się licznych reinterpretacji. Jednym z najbardziej uznanych specjalistów w dziedzinie jego analizy jest Pierre Bourdieu, który zdefiniował go jako: „zbiór rzeczywistych i potencjalnych zasobów, jakie związane są z posiadaniem trwałej sieci mniej lub bardziej zinstytucjonalizowanych związków wspartych na wzajemnej znajomości i uznaniu lub inaczej mówiąc z członkostwem w grupie - która dostarcza każdemu ze swych członków wsparcia w postaci kapitału posiadanego przez kolektyw (...)" (Bourdieu, 1986, s. 51).

W tym rozumieniu kapitał społeczny zaraz obok materialnego i kulturowego sprawia, że jednostka może być aktywna na różnych polach społecznych (Mularska-Kucharek, 2013, s. 14). Pojęcie to traktowane jest przez badacza dość instrumentalnie: „Zasób kapitału społecznego posiadany przez danego aktora zależy od rozmiaru sieci powiązań, jakie może on skutecznie zmobilizować i od zasobu kapitału (ekonomicznego, kulturowego i symbolicznego) posiadanego na 
własny rachunek przez każdego z tych, z którymi on jest powiązany" (Bourdieu, s. 50). Kapitał społeczny jest zatem wartością, którą odznaczają się wszyscy ludzie na świecie. Zdaniem H. Flapa jest on sumą potencjalnych przyszłych korzyści wynikających nie z wykonywania określonej pracy, ale dzięki kontaktom utrzymywanym z innymi ludźmi (Mularska-Kucharek, 2013, s. 153). Podobnie sądzi R.S. Burt, który w samych korzyściach z posiadanych kontaktów społecznych upatruje jego sedna (Burt, 2005). Co więcej, „sieci społeczne nie są postrzegane po prostu jako kolejne ograniczenie, ale jako wartość, przy pomocy której możliwe staje się dochodzenie do określonych rezultatów" (Bourdieu, 1986, s. 50). Konkludując, różnica polega na ilości i jakości tego zasobu oraz na tym, w jaki sposób jest on wykorzystywany przez jednostki.

Innym badaczem, który usiłował zgłębić i rozbudować koncepcję kapitału społecznego, jest James Coleman. W swej publikacji Fundations of Social Theory stwierdził, że jest on „naturalnym zasobem” znajdującym się w relacjach społecznych wewnątrz danej społeczności. Jego zdaniem tworzy się on „między ludźmi i wśród ludzi” (Coleman, 1990, s. 302). Dla Putnama kapitał społeczny to poziom zaufania oraz wartości wyznawane przez członków danej wspólnoty. Jak pisał: „Kapitał społeczny to te cechy organizacji społecznych, takich jak sieci (układy) jednostek lub gospodarstw domowych oraz powiązanych z nimi norm i wartości, które kreują efekty zewnętrzne dla całej wspólnoty” (Coleman, 1995, s. 65-78). Swoją konstatację czerpał ze stwierdzenia Colemana, który w 1990 roku napisał: „Tak jak inne postaci kapitału, kapitał społeczny jest produktywny, umożliwia bowiem osiągnięcie pewnych celów, których nie dałoby się osiągnąć gdyby go zabrakło. (...) Na przykład grupa, której członkowie wykazują, że są godni zaufania i ufają innym będzie w stanie osiągnąć znacznie więcej niż porównywalna grupa, w której brak jest zaufania. (...) We wspólnocie rolników (...), w której rolnikowi inni pomagają ułożyć w stogach siano i gdzie narzędzia są powszechnie pożyczane, kapitał społeczny pozwala każdemu $\mathrm{z}$ farmerów na wykonanie swojej pracy z mniejszym nakładem kapitału fizycznego w formie narzędzi i wyposażenia" (Coleman, 1990, s. 302-304).

O zaufaniu i normach relacji społecznych pisali również inni uczeni. Zdaniem Fukuyamy: „kapitał społeczny można najprościej zdefiniować jako zestaw nieformalnych wartości i norm etycznych wspólnych dla członków określonej grupy i umożliwiających im współpracę". Niezwykle istotne jest tutaj poczucie zaufania ludzi, które reguluje jakość ich relacji społecznych: „zaufanie działa niczym smar, który zwiększa wydajność funkcjonowania każdej grupy lub instytucji” (Fukuyama, 2003, s. 169). Putnam wprowadza rozgraniczenie na różne typy 
zaufania. Jego zdaniem mamy do czynienia z zaufaniem zagęszczonym (thick), stanowiącym wyznacznik relacji prywatnych oraz zaufaniem uogólnionym zwanym również rozproszonym (thin), odnoszącym się do relacji z innymi, obcymi nam ludźmi (Putnam, 2008, s. 14).

Według Moniki Mularskiej-Kucharek ideą leżącą u podstaw tego pojęcia są „indywidualne dążenia poszczególnych jednostek do jak najlepszej egzystencji” (Mularska-Kucharek, 2013, s. 210-215). Na tej podstawie definiuje ona kapitał społeczny jako „sieć relacji pomiędzy ludźmi i grupami, podzielane normy i wartości oraz zaufanie" (2013, s. 12). Stanowisko to koresponduje z dokonaniami Scota Mcleana i Johna Page’a, którzy sądzą, że sieci te generują zasoby i atuty, mogące być obiektami podlegającymi wycenie w różnych sytuacjach. Wynika z tego, że kapitał społeczny może być również towarem lub też czynnikiem określającym wartość wyprodukowanego dobra. Tę kwestię podnosił Putnam, twierdząc, że wiele osób tworzy sieci znajomości, które mają pomóc im w znalezieniu pracy dzięki temu, kogo znają, a nie ze względu na to, co wiedzą, czyli aspekt merytoryczny. Jego zdaniem kapitał społeczny „odnosi się do powiązań między jednostkami - sieci społecznych i norm wzajemności oraz wyrastającego z nich zaufania” (2008, s. 35). Struktura ta wytwarza określone sieci zależności. Jak stwierdzili Phillip H. Kim i Howard E. Aldrich: „w języku sieci społecznych, przyjaciele naszych przyjaciół są już naszymi przyjaciółmi, a nie obcymi” (Kim, Aldrich, 2005, s. 5). Warto tu również przywołać zdanie Marka S. Granovettera, który napisał: „Ponieważ jednostki wykorzystują kontakty społeczne w miejscu, w którym się znajdują i nie muszą ponosić dodatkowych inwestycji na ich wytworzenie, ich koszt jest mniejszy niż bardziej formalny sposób poszukiwania pracy. Ze względu na fakt, iż wcześniej istniejące sieci społeczne są nierównomiernie rozdzielone pomiędzy jednostki, niezależnie od procesów społecznych, które doprowadził do ich powstania, będą one tworzyły nierówne pola gry w obrębie rynku pracy, niezależnie od tego, czy aktorzy chcieli tego, czy nie" (Granovetter, 2005, s. 302).

Kapitał społeczny może być ponadto kumulowany oraz stanowić element twórczy dla potencjalnych dalszych działań podejmowanych przez jednostki w przyszłości. Coleman prezentuje kilka przykładów świadczących o tym, że pojęcie to należy definiować przez swoje funkcje (Coleman, 1990, s. 302). Jednym z nich jest radykalna organizacja studencka w Korei Południowej, której członkowie w ramach relacji wewnętrznych budują i wzmacniają swój kapitał społeczny. Colemana uważa, że każda organizacja czy instytucja, która stwarza możliwości podejmowania działań zbiorowych, ma wielką siłę sprawczą do wytwarzania kapitału wśród jej członków (1990, s. 303). 
Kolejnym wzorem relacji są te, zachodzące pomiędzy pacjentami a lekarzami. Coleman zauważył drastycznie spadające zaufanie Amerykanów do służby zdrowia, spowodowane złym stanem opieki medycznej oraz brakiem kompetentnych lekarza. Efektem tego jest ogromna liczba pozwów sądowych wytaczanych przez pacjentów, co jego zdaniem wpływa negatywnie na rozwój kapitału społecznego (1990, s. 303). W koncepcji idealistycznej relacja ta powinna opiera się na zaufaniu pacjenta i profesjonalizmie lekarzy, co wpłynęłoby na poziom zdrowia obywateli, zmniejszyło koszty leczenia, a przede wszystkim zbudowałoby trwałą więź między oboma podmiotami.

Innym przykładem jest historia matki, która przeniosła się wraz z rodziną z Detroit w USA do Jerozolimy. Po przeprowadzce stwierdziła, że czuje się spokojniejsza o swoje dzieci tutaj niż w rodzimym kraju. Powodem tego są odmienne normy społeczne. Mianowicie w dużym mieście Ameryki wszyscy są dla siebie anonimowi, a zatem bawiące się dzieci w parku, bez opieki swej matki, są narażone na niebezpieczeństwo. Normy społeczne obowiązujące w Jerozolimie sprawiają, że każde dziecko pozostawione bez opieki, znajdujące się w autobusie, parku czy na ulicy, staje się obiektem troski i zainteresowania innych dorosłych członków społeczeństwa (1990, s. 303).

Ostatnim przykładem są handlarze w Kairze, których relacje dla ludzi z zewnątrz są dość oryginalne. Mianowicie większość z nich specjalizuje się w wyrobach ze skóry. To jednak nie przeszkadza im w handlu innymi towarami, gdy klient będzie tego oczekiwał, lub też gdy ów poszukuje odmiennego asortymentu, w skierowaniu go bezpośrednio do znajomego handlarza, który oferuje dany towar. Zdarza się również, że za wyświadczenie takiej przysługi w dowód wdzięczności otrzymuje on określony procent wartości danej transakcji. Ten przykład ma być zdaniem Colemana dowodem na to, że kapitał społeczny może być środkiem do uzyskania kapitału finansowego i zbudowania relacji biznesowej (1990, s. 303).

O istotności kapitału społecznego można przeczytać również w cyklicznych raportach wydawanych przez Organizację Współpracy Gospodarczej i Rozwoju (Organisation for Economic Cooperation and Development - OECD), w których wyraźnie zostało zaznaczone, że ma on wpływ na poziom ludzkiego dobrostanu (OECD, 2001). Argumentem za tym mogą być słowa Agnieszki Rymszy, która twierdzi, że „kariera” kapitału społecznego „wydaje się mieć źródło w powszechnym przekonaniu, że jak kapitał finansowy (to, co się posiada) w czasach przednowoczesnych, kapitał ludzki (to, co się wie i potrafi) w epoce nowoczesnej, tak właśnie kapitał społeczny (to, kogo się zna, z kim się jest związanym) przesądza 
obecnie (w erze postnowoczesnej) zarówno o sukcesie jednostki, jak i grup społecznych" (Rymsza, 2007, s. 23-40). Podobną tezę głosi Coleman w swym artykule Social Capital in the Creation of Human Capital opublikowanym na łamach The American Journal of Sociology w 1988 roku, w którym podkreślił on znaczenie poziomu kapitału społecznego dla relacji międzyludzkich (Coleman, 1988, s. 118).

Brak jasno sprecyzowanej definicji kapitału społecznego nie oznacza jednak, że jego wartość naukowa jest znikoma. Jak twierdzi Putnam, jest on równie istotny jak prawo, umowy oraz racjonalność w stosunkach gospodarczych. Nie ma wątpliwości, że żaden z powyższych instrumentów nie mógłby funkcjonować, gdyby nie akceptacja obowiązujących norm społecznych, czyli świadomość istnienia określonego zespołu instrumentów regulujących relacje w państwie oraz zaufanie do ich efektywności. Należy podkreślić, że badania w tym obszarze mogą być prowadzone na różnych poziomach struktury społecznej. Pierwszym aspektem rozważań jest tzw. kapitał łączący (pomostowy), w którym kładziony jest nacisk na relacje jednostki z otoczeniem zewnętrznym oraz na więzi pomiędzy różnymi grupami społecznymi (Putnam, 1993, s. 14). To właśnie tutaj ów zasób (kapitał społeczny) wykorzystywany jest przez jednostki do realizacji własnych interesów (np. znalezienie wspomnianej pracy). Kolejnym jest kapitał wewnętrzny spajający (integracyjny), którego funkcją jest tworzenie sieci relacji między obywatelami w małych grupach społecznych, integrując członków w celu realizacji wewnątrzgrupowych interesów (1993, s. 14; s. 40-41). Z tego powodu zdaniem Colemana kapitał społeczny to nie jeden, a szereg podmiotów i zależności pomiędzy nimi. Naturalnie spotkać można definicje integrujące oba poglądy na ten temat, sprowadzające się do wskazania silnej relacji dwukierunkowej pomiędzy wewnętrzną a zewnętrzną sferą życia społecznego. Wśród badaczy kapitału społecznego można również wskazać na nurt, w którym kapitał społeczny rozumiany jest jako: cechy osobiste jednostki (tzw. osobisty kapitał społeczny), cechy grupy społecznej (grupowy kapitał społeczny), jak również w wymiarze makrostruktury społecznej, cechy całego społeczeństwa ujawniające się w relacjach wewnątrz państwa.

Należy wskazać, że kapitał społeczny to pojęcie wieloznaczne. Możliwe jest jednak wyznaczenie jego podstawowych składowych. Są to: sieci komunikacji i uczestnictwa powstałe między ludźmi; zaufanie do ludzi oraz instytucji oraz wartości i normy rządzące mechanizmami całej sieci relacji społecznych. Jest to jednak jedynie konstrukcja teoretyczna. W praktyce na poziom kapitału społecznego wpływa wiele innych czynników. Wyróżnić tu należy obowiązujące 


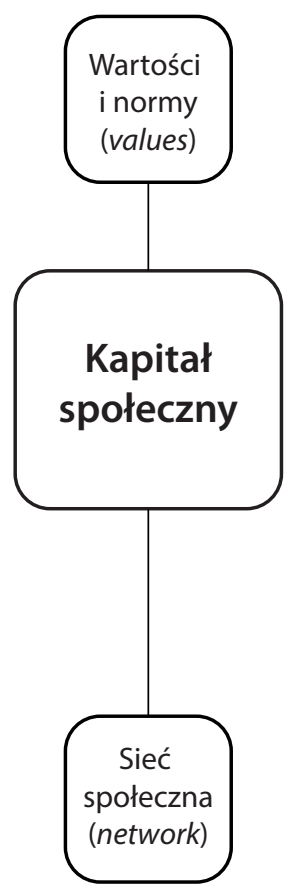

Schemat 1. Budowa kapitału społecznego

Źródło: Opracowanie własne na podstawie:

Putnam, 2008 oraz Mularska-Kucharek, 2013.

prawodawstwo, pobudzające lub ograniczające sferę aktywności społeczeństwa. Następnie poziom gospodarczy regionu oraz państwa, będący potencjalnym czynnikiem do zawierania umów i wchodzenia w spółki z innymi członkami społeczeństwa. Wreszcie należy podkreślić znaczenie działalności władz lokalnych jako bezpośredniej politycznej reprezentacji wspólnoty samorządowej. Inną zmienną może być również aktywność lokalnych struktur partii politycznych, które mogą pozostawać w oderwaniu od lokalnej tkanki społecznej, lub wręcz przeciwnie - silnie ją przenikać w celu pozyskania członków.

Na podstawie zaprezentowanych danych należy uznać, że kapitał społeczny stanowi zestaw zmiennych wpływających na dynamikę aktywności społecznej jednostki, w skład których wchodzą: uświadomiony poziom zaufania, sieć komunikacji i uczestnictwa oraz wyznawane wartości i normy. Analizując aktywność obywatelską jako przykład działania zbiorowego, warto zastanowić się nad czynnikami wpływającymi na nią, z których ważny jest potencjał obywatelski. Na podstawie dotychczasowych badań należy stwierdzić, że jest to zdolność 
grupy ludzi do podjęcia działań w sferze polityki, których przykładami mogą być: zorganizowanie pikiety, manifestacji czy udział w wyborach. Owa aktywność zbiorowa nie zawsze musi sprowadzać się do działalności politycznej, niekiedy ma ona charakter czysto społeczny i dotyczy pracy na rzecz lokalnej wspólnoty w postaci: wspólnego sprzątania parku, sadzenia roślin czy organizowaniu sąsiedzkich pikników. Wszystkie te przykłady należy rozumieć jako swego rodzaju potencjał wspólnoty, rozumiany przez ogólną zdolność jednostek do współdziałania. Stąd kolejnym aspektem analizy winna być refleksja nad wpływem czynników budujących poziom kapitału społecznego jednostek na proces kształtowania się potencjału obywatelskiego społeczeństwa.

\section{ANALIZA WPŁYW KAPITAŁU SPOŁECZNEGO NA SPOŁECZEŃSTWO OBYWATELSKIE}

Kluczową kwestią wymagającą rozstrzygnięcia jest to, czy kapitał społeczny należy rozumieć jako pozytywny, negatywny, czy neutralny czynnik wpływający na społeczeństwo obywatelskie i państwo? Na podstawie dotychczasowych rozważań można stwierdzić, że ów zasób nie jest równomiernie zdyskontowany pośród wszystkich jednostek. Rodzi to obawy o niebezpieczne rozwarstwienie społeczeństwa. Część osób wykazuje zaufanie do innych współobywateli, jednocześnie dystansując się od instytucji państwa. Z kolei inna grupa ludzi uważa, że tylko administracja publiczna, wolne sądy, prawo oraz służby mundurowe uchronią ich od kradzieży własnego mienia, pobicia czy oszustwa. Przejawem tego rodzaju obaw są powstające coraz to nowsze zamknięte osiedla mieszkalne, będące przejawem poczucia zagrożenia ze stronny innych członków społeczeństwa, jednocześnie stanowiąc empiryczny dowód na postępujące rozwarstwienie społeczne.

Badacze nie są w stanie jednoznacznie rozwikłać sporu o charakter kapitału społecznego. Słynne stwierdzenie Putnama, mówiące o tym, że wiele osób znajduje pracę nie z powodu swoich kompetencji i umiejętności, lecz dlatego, że kogoś znają, czyli mówiąc potocznie: „po znajomości”, świadczy o tym, że stanowi on ważny czynnik stabilności ekonomicznej jednostek i może być obiektem rywalizacji między nimi. Tu również mamy do czynienia z dychotomicznym pojmowaniem tego zasobu. Jego negatywnym przejawem będzie nepotyzm i korupcja, czyli promowanie osób pozostających w kręgu naszych bliskich relacji kosztem innych członków społeczeństwa. Z kolei pozytywnym aspektem kapitału 
społecznego może być jego wykorzystanie w celu pozyskania lepszego, bardziej wykształconego i doświadczonego pracownika, który zostanie polecony przez osoby przez nas uważane za godne zaufania lub wręcz za autorytet w danej dziedzinie. Osią sporu są tu również wartości i normy współżycia społecznego. $\mathrm{Na}$ tym polu może dochodzić do rozbieżności powodujących silne rozwarstwienie społeczne. Przykładem mogą być różnego rodzaju grupy społeczne, dążące do zabezpieczenia własnych interesów, których aktywność, jakkolwiek będąca działalnością obywatelską oraz stanowiąca przejaw wysokiego kapitału społecznego, sprowadza się do partycypacji bliskiej amoralnemu familizmowi, czyli kosztem innych grup: społecznych lub zawodowych, czy też rozmaitych mniejszości.

Trudno zatem jest jednoznacznie ocenić, czy kapitał społeczny to pozytywny czynnik rozwoju społeczeństwa i państwa. Wydaje się, że zasadne jest stwierdzenie, że natura kapitału społecznego jest neutralna, a samo jego wykorzystanie może być nacechowane pozytywnie lub negatywnie (Barczykowska, 2012). Odwołując się do pozostały trzech form kapitału: finansowego (to, co się posiada) oraz ludzkiego (to, co się wie i potrafi), można zauważyć ich neutralny charakter. Konkludując, kapitał społeczny, tak jak inne rodzaje zasobów, stanowi obiektywny wyznacznik rozwoju społeczeństwa. Fakt, że przybiera on niekiedy postać pozytywnie lub negatywnie wpływającą na wspólnotę, pozostaje w gestii człowieka, w oparciu o jego potrzeby, interesy oraz racjonalny osąd i dyspozycję moralną.

W celu lepszego zrozumienia natury kapitału społecznego warto posłużyć się modelem pokazującym jego teoretyczny dychotomiczny rozkład na osi o umownym punkcie zero, który stanowi brak kapitału społecznego i pewnej wartości maksymalnej, czyli posiadaniu możliwie największej wartości tego zasobu.

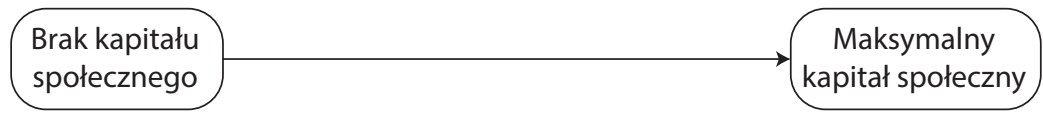

Schemat 2. Dychotomiczny rozkład kapitału społecznego

Źródło: Opracowanie własne.

Na powyższym schemacie można zauważyć, że w przypadku analizy kapitału społecznego mamy do czynienia z pewnymi ekstremami, to jest sytuacjami, kiedy dana jednostka nie posiada żadnego zasobu lub cieszy się największym możliwym kapitałem. Pierwszy z nich określilibyśmy jako przejaw pustelniczego 
życia na odludziu, np. na bezludnej wyspie, na której nie zachodzą żadne relacje społeczne. Drugi natomiast to odwzorowanie potencjalnej sytuacji, w której jednostka odznacza się pełnym zaufaniem horyzontalnym i wertykalnym, kieruje się najwyższymi normami wzajemności i wartościami moralnymi, a także posiada niemal nieograniczoną sieć relacji komunikacji i uczestnictwa. Oczywiście przedstawione sytuacje są typami idealnymi i nie występują w praktyce. Uświadamiają nam one jednak, że kapitał społeczny każdego z nas mieści się gdzieś na osi pomiędzy nimi. Można zatem uznać, że korzystne z punktu widzenia każdego obywatela jest dążenie do zmaksymalizowania tego zasobu, mając jednocześnie świadomość, że osiągnięcie maksimum jest niemożliwe. Stwierdzenie to może być uznane za karkołomne, jednakże spośród dwóch możliwych kierunków postępowania, dla państwa i społeczeństwa, bardziej korzystne wydają się dążenia do osiągnięcia najwyższej możliwej wartości danego parametru.

Oprócz wskazania na aspekt ilościowy kapitału społecznego warto również wskazać na jego wymiar jakościowy. Tu ponownie pojawia się pytanie, czy kapitał społeczny jest pozytywny i negatywny? Zależność ta ponownie wynika $z$ tego, w jakim celu zostanie on wykorzystany przez daną jednostkę czy grupę społeczną. Stworzony w schemacie trzecim układ współrzędnych obrazuje ten problem.

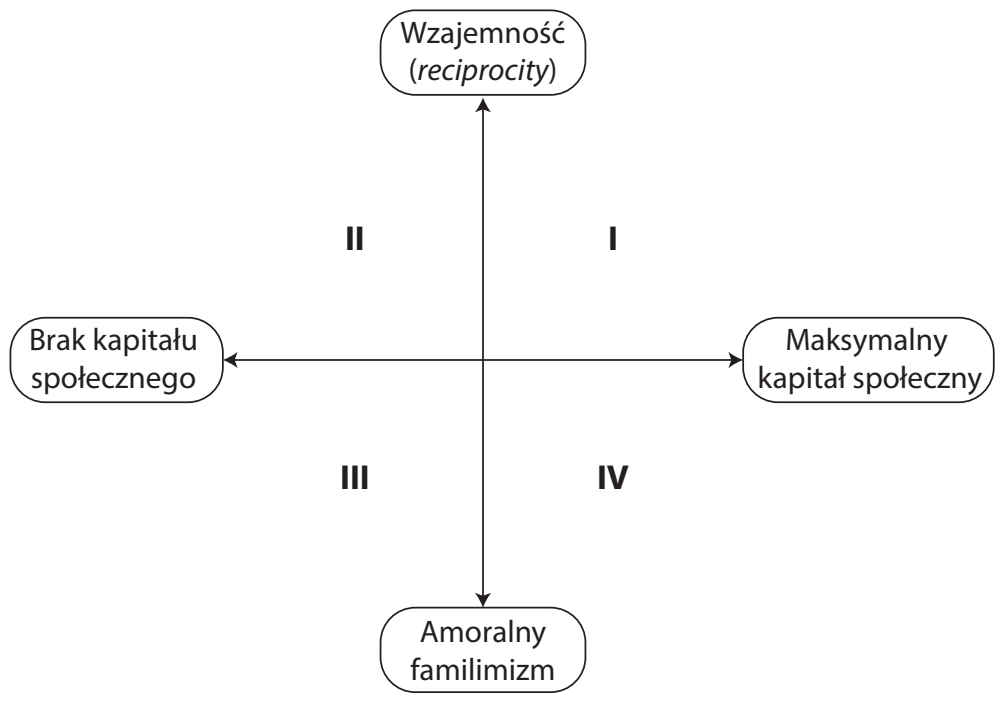

Schemat 3. Układ współrzędnych kapitału społecznego

Źródło: Opracowanie własne. 
Zaprezentowany model również stanowi element teoretycznych rozważań nad kapitałem społecznym. Osoby posiadające duży kapitał społeczny ukierunkowane na cele wspólnotowe, które określić należy jako dążenie do rozwoju społeczeństwa obywatelskiego, z pewnością znajdą się w pierwszej ćwiartce powyższego układu. Na drugim biegunie mamy jednostki posiadające ów zasób, jednakże skierowany na partykularne interesy wąskiej grupy osób, czego efektem może być postępujące rozwarstwienie społeczne (czwarta ćwiartka). W ćwiartce drugiej znajdą się osoby, których kapitał społeczny jest niewielki, jednakże starają się one działać w sferze publicznej. Będą to osoby, które są w fazie jego budowy, np. młodzi ludzie od niedawna będący członkami organizacji pozarządowych. Ostatnia grupa osób, które umiejscowilibyśmy w trzeciej ćwiartce, to współobywatele niezważający na potrzebę budowy relacji społecznych, zdeterminowani do wykorzystania tych swoich niewielki zasobów do zrealizowania partykularnych interesów. Przedstawiony schemat zdaje się być pożytecznym w celu zrozumienia zjawiska zmienności poziomu kapitału społecznego wewnątrz społeczeństwa. Należy mieć na uwadze, że tego rodzaju zasób „nie jest dany raz na zawsze”. Posiadać kapitał społeczny to znaczy rozwijać go, a zatem umacniać się w przekonaniu ufności do osób i instytucji, podtrzymywać lub rozwijać relacje z innymi ludźmi oraz dawać świadectwo postępowania zgodnego z ogólnie przyjętymi w społeczeństwie normami i wzorcami.

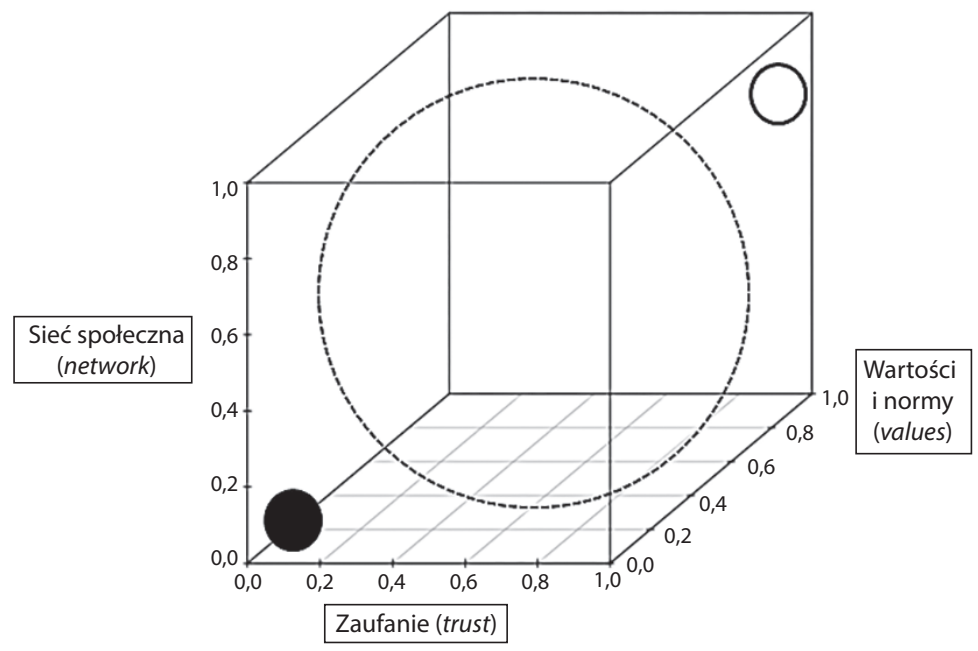

Schemat 4. Przestrzenny schemat kapitału społecznego

Źródło: Opracowanie własne. 
Problematykę rozwoju i zmienności poziomu kapitału społecznego pokazuje w sposób ujednolicony czwarty schemat. Trójwymiarowe ujęcie sieci społecznych, zaufania oraz norm i wartości uświadamia, jak trudną i wieloznaczną kwestią jest proces budowy omawianego zasobu. Na przedstawionym przykładzie obszar oznaczony kolorem czarnym ukazuje brak kapitału społecznego, natomiast biały jego postać maksymalną. W rzeczywistości obie sytuacje nie występują, gdyż jak zostało wcześniej stwierdzone, są typami idealnymi. Należy zatem stwierdzić, że kluczowym obszarem badań nad rozwojem kapitału społecznego powinien być obszar znajdujący się pomiędzy nimi, który na powyższym schemacie został oznaczony przerywaną liną. Jego umiejscowienie jest hipotetyczne i stanowi jedynie konstrukt myślowy, mający na celu wskazanie przestrzeni znajdującej się pomiędzy typami idealnymi. To jednak dalej nie rozwiewa wszelkich wątpliwości związanych z kształtowaniem się kapitału społecznego. Błędnym byłoby założenie, że osoby odznaczające się niewielkim kapitałem społecznym, który na osi minimum - maksimum (0-1) umieścilibyśmy w przedziale $0.3-0.4$, nie są zdolne do działania na rzecz wspólnoty i nie przyczyniają się do budowy społeczeństwa obywatelskiego. Badania opinii publicznej dowodzą, że ludzie chętnie wierzyliby współobywatelom, jednakże nie są w stanie wypracować w sobie takiego przekonania, gdyż omawiane wcześniej normy i wartości społecznie akceptowane zbyt często są przez tychże łamane (CBOS, 2016, 2013). Podobnie sytuacja wygląda w przypadku zaufania społecznego. Przedstawiciele organizacji pozarządowych, działających w przestrzeni lokalnej czy ogólnokrajowej, dążą do poprawy jakości życia społeczno-politycznego. Nie oznacza to jednak, że ich zaufanie do instytucji państwa i polityków jest znaczące. W dużej mierze ich działanie podyktowane jest właśnie brakiem owego zaufania, a ich aktywność ma być swego rodzaju przeciwwagą dla establishmentu oraz próbą odnowy oblicza polityki i podniesienia jakości demokracji (Stowarzyszenie Klon/Jawor, 2015, s. 36).

Powyższa analiza skłania do refleksji nad kapitałem społecznym, w szczególności w wymiarze jakościowym. Należy stwierdzić, że mniej istotne jest to, jak wielkie zaufanie posiadamy do innych ludzi oraz instytucji, jakimi normami kierujemy się w swoim postępowaniu oraz w jak licznej grupie organizacji pozarządowych działami, niż to, czy nasza aktywność nie jest odosobniona oraz czy nasz wkład w budowę potencjału obywatelskiego przynosi wymierne efekty. Powszechne wyobrażenie na temat społeczeństwa i państwa może być błędne, a aktywność obywatelska powodować zniechęcenie sferą publiczną, zamiast pobudzać do wytężonej pracy. Dlatego tak ważna jest dbałość o wymienione wyznaczniki kapitału społecznego. Efektów tej działalności nie sposób oczeki- 
wać w krótkim okresie, gdyż, jak stwierdził Dahrendorf, zegar społeczeństwa obywatelskiego jest tym najmniej dynamicznym, ponieważ wymaga przemian w mentalności i kulturze społeczeństwa.

\section{ZAKOŃCZENIE}

Analiza procesu kształtowania się w państwie społeczeństwa obywatelskiego dowodzi, że niezwykle istotna dla tego procesu jest troska o rozwój kapitału społecznego najwyższej jakości. Jednym z obszarów, w jakim może on przynieść pozytywne skutki, jest kultura polityczna. Mianowicie, jeśli osoby biorące udział w procesie politycznym będą posiadały ów zasób najwyższej próby, będą mogły pozytywnie wpłynąć na jakość i merytoryczność: debaty publicznej, rywalizacji wyborczej partii politycznych, a w konsekwencji na stanowionego w państwie prawa. Aby to osiągnąć, potrzebna jest organiczna praca u podstaw, czyli edukacja pozwalająca na poprawę relacji społecznych w tych najmniejszych, lokalnych społecznościach. Inną z konsekwencji tego działania może być większa świadomość obywatelska oraz wiedza wyborców, którzy wybierając swoich przedstawicieli, będą kierować się w mniejszym niż obecnie stopniu pobudkami emocjonalnymi, a bardziej racjonalnością i poczuciem odpowiedzialności za wspólnotę.

Na podstawie powyższych konstatacji należy stwierdzić, że rozwój społeczeństwa obywatelskiego stanowi ważny czynnik wpływający na jakość systemu politycznego państwa. Poczynając od pracy nad poziomem wiedzy, umiejętności i kompetencji obywatelskich, a kończąc na mobilizacji społeczeństwa do udziału w procesie zarządzania własnym państwem, jesteśmy w stanie podnieść jakość kultury politycznej. Proces ten musi jednak opierać się na rzetelnej i sumiennej edukacji najmłodszych obywateli, gdyż tylko wypracowanie najwyższych standardów pozwoli na podniesienie jakości zarówno partycypacji społecznej, jak i politycznej. Oprócz kwestii jakościowych należy również stwierdzić prawdziwość hipotezy mówiącej o tym, że społeczeństwo obywatelskie stanowi czynnik regulujący udział obywateli w procesach politycznych toczących się w państwie. Bardziej świadome społeczeństwo, chętniej i z większą determinacją będzie zabierać głos w sprawach ważnych dla całego państwa, jak również dla samorządu lokalnego. Natomiast podnoszenie jakości owego zaangażowania sprawi, że jego efektywność zaowocuje zwiększającą się liczbą osób biorących w nim udział, a przez to podniesieniem się potencjału obywatelskiego społeczeństwa. 
W dalszej kolejności należy wskazać na kapitał społeczny, który stanowi ważny czynnik determinujący zasięg oraz jakość relacji społecznych. Mechanizm jego powstawania można określić jako proces wytwarzania w świadomości członków wspólnoty pewnych kompetencji i dyspozycji, aż po etap podejmowania przez nich działań zbiorowych. Niestety jest on narażony na liczne problemy braku zaufania, zerwania więzi społecznych oraz upadku norm i wartości społecznie pożądanych. Tego rodzaju zmienność stanowi naturalną cechę procesu tworzenia się społeczeństwa obywatelskiego oraz świadczy o tym, czy obywatele danego państwa lub też członkowie lokalnej wspólnoty stanowią społeczeństwo obywatelskie o bardziej lub mniej rozwiniętej formie i strukturze. Na podstawie przedstawionych argumentów należy uznać hipotezę, mówiącą, że kapitał społeczny stanowi czynnik determinujący jakość społeczeństwa obywatelskiego oraz całego systemu politycznego za poprawną.

Zainteresowanie koncepcją kapitału społecznego przez szerokie audytorium badaczy z zakresu nauk społecznych dowodzi, że rozważania nad sferą społeczno-polityczną państwa nie ograniczają się jedynie do podsystemowych analiz np. kultury politycznej, systemu wyborczego lub prawnego. Zostało dostrzeżone i wykazane, że wszystkie te niezwykle istotne płaszczyzny funkcjonowania państwa, będące wyznacznikami jakości demokracji, mają swoje wspólne korzenie. Są nimi postawy i relacje społeczne, określające świadomość obywateli, którymi wszyscy jesteśmy bez względu na wykonywany zawód czy pełnioną funkcję publiczną. Omawiane tu społeczeństwo obywatelskie stanowi obszar, dzięki któremu w sposób ewolucyjny, a tym samym ustanawiający bardziej trwałe rozwiązania, jesteśmy w stanie wpłynąć na proces funkcjonowania państwa. Dotyczy to równie silnie aspektu społecznego, czyli partycypacji w ramach sąsiedzkiej współpracy i kooperacji, jak również aktywności politycznej, mającej na celu artykulację i realizację interesów rozmaitych zbiorowości ludzkich. W tym wymiarze koncepcja kapitału społecznego pozwala na bardziej analityczną i wnikliwszą refleksję nad mechanizmem kształtowania się w państwie sfery obywatelskiej. Należy jednak wystrzegać się uznawania społeczeństwa obywatelskiego oraz samego kapitału społecznego jako panaceum na wszelkie problemy współczesnego świata. Jak zostało podkreślone, oba pojęcia mają charakter neutralny, a to jaki będą miały one charakter i czy przyniosą pozytywne rezultaty w wymiarze stabilizacji i modernizacji systemu politycznego, zależy jedynie od ich wykorzystania przez obywateli oraz elitę polityczną. 
Bibliografia:

Arystoteles. Polityka. Pobrane z: http://libertarianin.org/Ebooks/Arystoteles\%20-\%20 Polityka.pdf.

Banfield, E. (1958). The Moral Basis of a Backward Society. New York: The Free Pres.

Barber, B. (2001). Dżihad kontra McŚwiat. Warszawa: Muza SA.

Barczykowska, A. (2012). Pozytywny, negatywny czy neutralny? Pytanie o naturę kapitału społecznego. Studia Edukacyjne, 22.

Bourdieu, P. (1986). The Forms of Capital. W: J. Richardson (red.). Handbook of Theory and Research for the Sociology of Education. New York: Greenwood Pres.

Buchanan, J.M. (1997). Finanse publiczne w warunkach demokracji. Warszawa: Wydawnictwo Naukowe PWN.

Burt, R.S. (2005). Brokerage \& closure. An introduction to social capital. Oxford: Oxford University Pres.

CBOS. (2013). O przestrzeganiu prawa i funkcjonowaniu wymiaru sprawiedliwości w Polsce. CBOS. Komunikat z badań nr BS/5/2013. Pobrane z: http://www.cbos.pl/ SPISKOM.POL/2013/K_005_13.PDF.

CBOS. (2016). Zaufanie społeczne, komunikat $z$ badań nr 18/2016. Pobrane z: http:// www.cbos.pl/SPISKOM.POL/2016/K_018_16.PDF.

Chodubski, A. (2009). Społeczeństwo obywatelskie i jego powołanie. W: A. Chodubski, L. Kacprzak, K. Pająk (red.). Instytucje państwa a społeczeństwo obywatelskie. Piła: Państwowa Wyższa Szkoła Zawodowa im. Stanisława Staszica w Pile.

Chodubski, A. (2012). Regiony a społeczeństwo obywatelskie w europejskiej rzeczywistości kulturowej. W: L. Kacprzak, B. Koszel, A. Marcinkowski (red.). Społeczeństwo obywatelskie jako wspólne dobro. Piła: Wydawnictwo Państwowa Wyższa Szkoła Zawodowa w Pile.

Collins, R. (2004). Interaction Ritual Chain. Princeston: Princeton University Pres.

Coleman, J. (1988). Social Capital in the Creation of Human Capital. The American Journal of Sociology, 94.

Coleman, J. (1990). Fundations of Social Theory. Cambridge, Massachusetts and London: The Belknap Press of Harvard University Pres.

Dahrendorf, R. (1990). Reflections on the Revolution in Europe: In a letter intended to have been sent to a gentleman in Warsaw. New York: Times Books.

Elias, N. (2008). Społeczeństwo jednostek. Warszawa: Wydawnictwo IFiS PAN. Fukuyama, F. (1997). Koniec historii. Poznań: Z-sk i Spółka.

Enten, H. (2015). Why Donald Trump Isn't A Real Candidate, In One Chart. Pobrane z: https://fivethirtyeight.com/features/why-donald-trump-isnt-a-real-candidatein-one-chart/.

Fukuyama, F. (2003). Kapitał społeczny. W: L.E. Harrison, S.P. Huntington (red.). Kultura ma znaczenie. Poznań: Z-sk i Spółka.

Fukuyama, F. (2005). Budowanie Państwa, Władza i ład międzynarodowy w XXI wieku. Poznań: Dom Wydawniczy Rebis. 
Gallo, A. (2017). Dealing with Democrats, Trump's anti-establishment credentials shine. Pobrane z: http://thehill.com/opinion/white-house/350730-dealing-withdemocrats-trumps-anti-establishment-credentials-shine.

Goffman, E. (1986). The Interaction Order. American Sociological Review, 48(1). Granovetter, M. (2005). The Impact of Social Structure on Economic Outcomes. Journal of Economic Perspective, 19(1).

Greven, T. (2016). The Rise of Right-wing Populism in Europe and the United States A Comparative Perspective, Fundacja im. Friedricha Eberta. Pobrane z: http://www. fesdc.org/fileadmin/user_upload/publications/RightwingPopulism.pdf.

Greven, T. (2016). The Rise of Right-wing Populism in Europe and the United States A Comparative Perspective. Berlin: Fundacja im. Friedricha Eberta.

Hanifan, J. (1916). The Rural School Community Center. The Annals of the American Academy of Political and Social Science, 67.

Hartleb, F. (2015). Here to stay: anti-establishment parties in Europe. European View, $14,39-49$.

Hobbes, T. (1954). Lewiatan, czyli materia, forma i władza państwa kościelnego i świeckiego. Warszawa: Wydawnictwo Naukowe PWN.

Holcombe, R.A. (1997). Theory of the Theory of Public Goods. Review of Austrian Economics, 10(1). Pobrane z: http://www.hayek.sk/wp-content/uploads/2012/12/ The-Theory-of-Theory-of-Public-Goods.pdf.

Howorth, J., Schmidt, V. (2016). Brexit: What happened? What is going to happen?. Politique étrangère, 4, 123-138. Pobrane z: https://www.ifri.org/sites/default/files/ atoms/files/howorth_en_politique_etrangere_vol._81_ndeg_4_hiver_2016-2017. pdf.

Hume, D. (1739). Traktat o naturze ludzkiej - wyd. II, tłum. Cz. Znamierowski. Pobrane z: http://bacon.umcs.lublin.pl/ lukasik/wp-content/uploads/2012/09/Hume-traktat-o-naturze-ludzkiej.pdf.

Kaźmierczak, T.M., Rymsza, M. (2007). Kapitał społeczny. Ekonomia społeczna. Warszawa: Instytut Spraw Publicznych.

Kim, P.H., Aldrich H.E. (2005). Social Capital and Entrepreneurship. Foundations and Trends ${ }^{\circledast}$ in Entrepreneurship, 1(2).

Le Bon, G. (2004). Psychologia tłumu. Kęty: Antyk.

Locke, J. (1992). Dwa traktaty o rządzie. Warszawa: Wydawnictwo Naukowe PWN.

Masłyk, T. (2014). Postulaty versus rzeczywistość. O postawach Polaków wobec ustroju demokratycznego. W: M. Baranowski (red.). Demokracja i rola obywatela. O napięciu pomiędzy państwem, społeczeństwem i procesami globalizacyjnymi. Poznań: Wydawnictwo Naukowe Wydziału Nauk Społecznych UAM.

McCarthy, T. (2015). Here's Why Donald Trump Won't Win the Republican Presidential Nomination. Pobrane z: https://www.theguardian.com/us-news/2015/aug/22/ donald-trump-wont-win-republican-presidential-nomination.

Mularska-Kucharek, M. (2012). Kapitał społeczny mieszkańców Łodzi w ujęciu przestrzennym. ACTA UNIVERSITATIS LODZIENSIS, Folia Geographica Socio-Oeconomica, 12. 
Mularska-Kucharek, M. (2013). Kapitał społeczny a jakość życia na przykładzie zbiorowości wielkomiejskiej. Łódź:. Wydawnictwo Uniwersytetu Łódzkiego.

OECD. (2001). The Well-being of Nations. The Role of Human and Social Capital, Education and Skills. Pobrane z: http://www.oecd.org/site/worldforum/33703702.pdf.

Pietrzyk-Reeves, D. (2012). Idea społeczeństwa obywatelskiego. Współczesna debata i jej źródła. Toruń: Wydawnictwo Naukowe Uniwersytetu Mikołaja Kopernika.

Putnam, R. (1993). Demokracja w działaniu. Tradycje obywatelskie we współczesnych Włoszech. Warszawa: Znak, Fundacja Batorego.

Putnam, R. (1995). Bowling Alone: America's Declining Social Capital. Journal of Democracy, 6(1).

Putnam, R. (2008). Samotna gra w kręgle. Upadek i odrodzenie wspólnot lokalnych w Stanach Zjednoczonych. Warszawa: Znak, Fundacja Batorego.

Richardson, J. (1986). Handbook of Theory and Research for the Sociology of Education. New York: Greenwood Pres.

Schumpeter, J. (2003). Capitalism, Socialism and Democracy. New York: Harper \&. Brothers.

Simmel, G. (1964). Conflict \& The Web of Group-Affiliations. New York: Free Pres.

Simmel, G. (1971). On Individuality and Social Forms. Chicago: University of Chicago Pres.

Simmel, G. (2006). Socjologia. Warszawa: Wydawnictwo Naukowe PWN.

Skinner, Q. (1978). The Foundations of Modern Political Thought. Cambridge: Cambridge University Pres.

Smith, D. (2016). How Trump Won the Election: Volatility and a Common Touch. Pobrane z: https://www.theguardian.com/us-news/2016/nov/09/how-did-donald-trump-win-analysis.

Sztompka, P. (2016). Kapitał społeczny. Teoria przestrzeni międzyludzkiej. Kraków: Znak. Tocqueville de., A. (2005). O demokracji w Ameryce. Warszawa: Fundacja Aletheia.

Turner, J.H. (2002). Face to Face. Toward a Sociological Theory of Interpersonal Behavior. Stanford: Stanford University Pres.

Wąsowicz, M. (2016). Morgan Stanley wskazat skutek Brexitu, który do tej pory ignorowaliśmy. Pobrane z: https://businessinsider.com.pl/polityka/brexit-mozespowodowac-wzrost-poparcia-dla-populistow-w-europie/044912d.

Stowarzyszenie Klon/Jawor (2015). Wizerunek organizacji pozarządowych. Raport $z$ badania. Warszawa: Stowarzyszenie Klon/Jawor.

Woolcock, M. (2001). The Place of Social Capital in Understanding Social and Economic Outcomes. Canadian Journal of Policy Research, 2(1). 